Vážené kolegyně a vážení kolegové,

na minulém Sympoziu Neurologie pro praxi v Tatranské Lomnici jsem vyzval kolegy, aby nespoléhali automaticky na popisy neurozobrazovacích snímků radiologem, ale sami si je kriticky prohliželi. Radiolog s všeobecným vzděláním někdy nemá dostatečné zkušenosti se zobrazováním CNS (typicky chybné popisy nacházíme u pacientů s epilepsii) a nezná klinické souvislosti. Z diskuze vyplynulo, že naši neurologové, především pracující mimo kliniky, mohou mít s hodnocením snímku CNS problém. Často chybi praxe a zkušenost. Rozhodli jsme se proto zavést do Neurologie pro praxi novou rubriku, ve které budeme stručně prezentovat zajímavé a poučné snímky. Rubriku bude editovat člen užší redakční rady Neurologie pro praxi prof. MUDr. Milan Brázdil, Ph.D.

Potěší nás, pokud se i Vy rozhodnete podělit se s námi o zajímavé snímky z Vaší praxe.

prof. MUDr. Ivan Rektor, CSC. predseda redakční rady Neurologie pro praxi

\title{
Neurozobrazovací kazuistika
}

\section{MUDr. Martin Pail, Ph.D.', MUDr. Marta Pažourková2, prof. MUDr. Milan Brázdil, Ph.D., 3}

${ }^{1}$ Centrum pro epilepsie Brno, I. neurologická klinika, FN u sv. Anny v Brně a LF MU, Brno

${ }^{2}$ Radiologická klinika, FN u sv. Anny v Brně a LF MU, Brno

${ }^{3}$ Středoevropský technologický institut, CEITEC MU, Brno

Pacientka, narozená v roce 1951, se symptomatickou epilepsií na podkladě strukturální léze (kavernom) v oblasti pólu a meziotemporálních struktur temporálního laloku vpravo.

Rozvoj epilepsie od 62 let, klinická manifestace parciálními záchvaty s komplexní symptomatologií temporálního charakteru, bez aury. Vysoká frekvence záchvatů (denní) s postupně narůstající četností. Terapie levetiracetamem v adekvátních dávkách byla bez efektu. V 64 letech pacientka podstoupila v rámci epileptochirurgického programu (Centrum pro epilepsie Brno) rozšířenou lezionektomii s peroperační elektrokortikografií. Histologicky kavernózní angiom, bez známek dysplazie. Nyní jeden rok po operaci je bez záchvatů (Engel IA), bez neurologického deficitu.

Obr. 1. T2 v.o. (fse = fast spin echo) v transverzální rovině - typický obraz kavernomu s, popcornovitou” strukturou a asignálním lemem v pravém temporálním laloku meziotemporálně

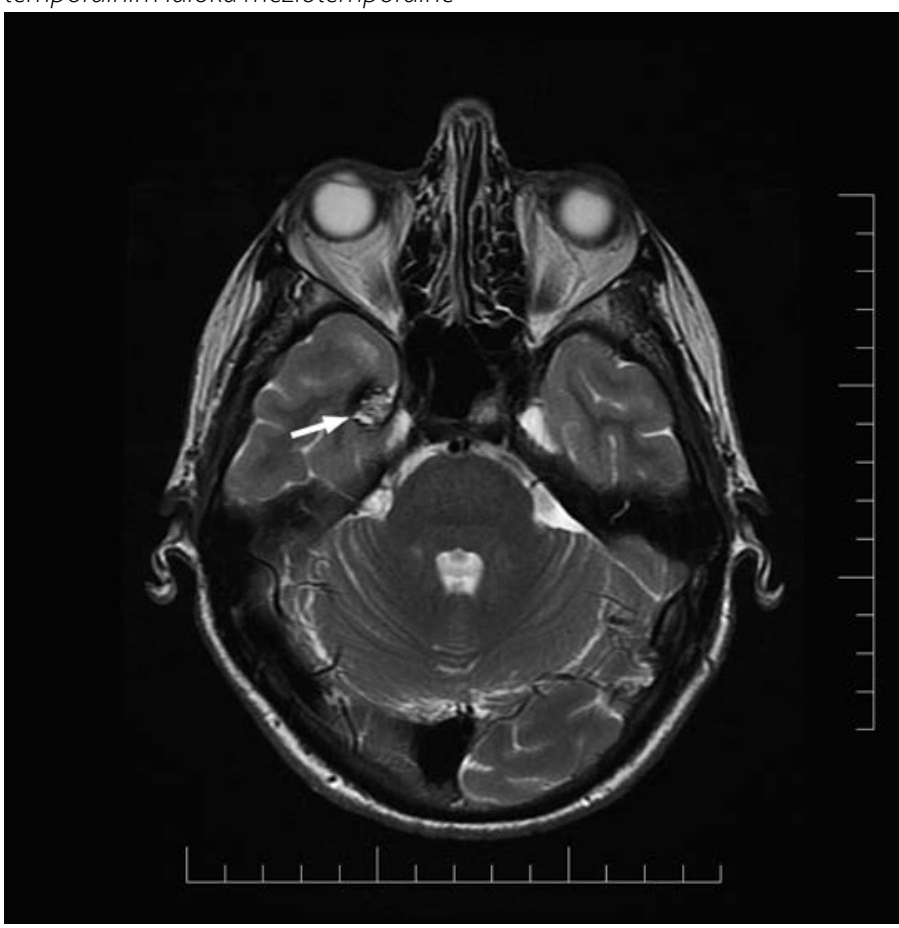

Obr. 2. T2 v.o. (fse) v koronární rovině - koronární rovina je nutná pro posouzení meziotemporálních struktur a vztahu léze k nim; kavernom je uložen při ventrokaudálním okraji pravé amygdaly, okrajově zasahuje do gyrus parahippocampalis a do mediálního okraje gyrus temporalis sup. pri pólu T laloku

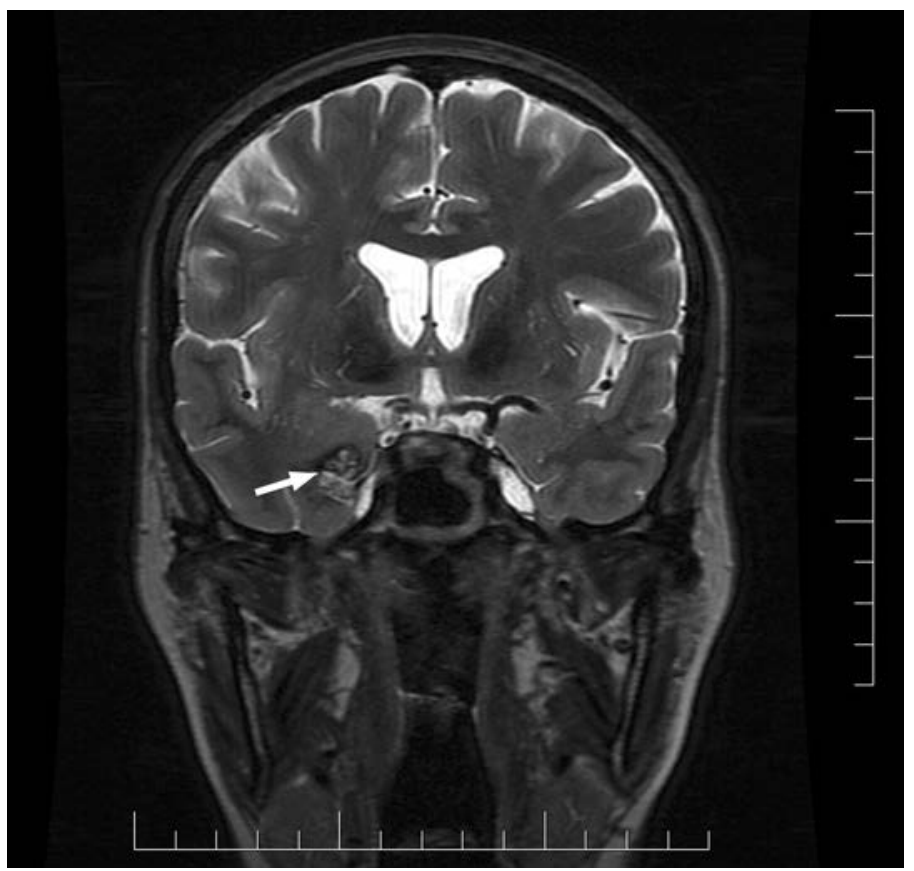

KORESPONDENČNÍ ADRESA AUTORA:

MUDr. Martin Pail, Ph.D., martin.pail@fnusa.cz

I. neurologická klinika, FN u sv. Anny v Brně, Pekařská 53, 65691 Brno

Cit. zkr: Neurol. praxi 2017; 18(1): 62-63 
NEUROZOBRAZOVACÍ KAZUISTIKA

Obr. 3. T1 v.o (flair) na T1 v.o. je zvl. v tomto prípadě léze podstatně méně nápadná s jen diskrétními tečkovitými centrálními hyperintenzitami, většinou bývá na T1 v.o. centrálně výrazněji hyperintenzní, také "popcornovité" struktury

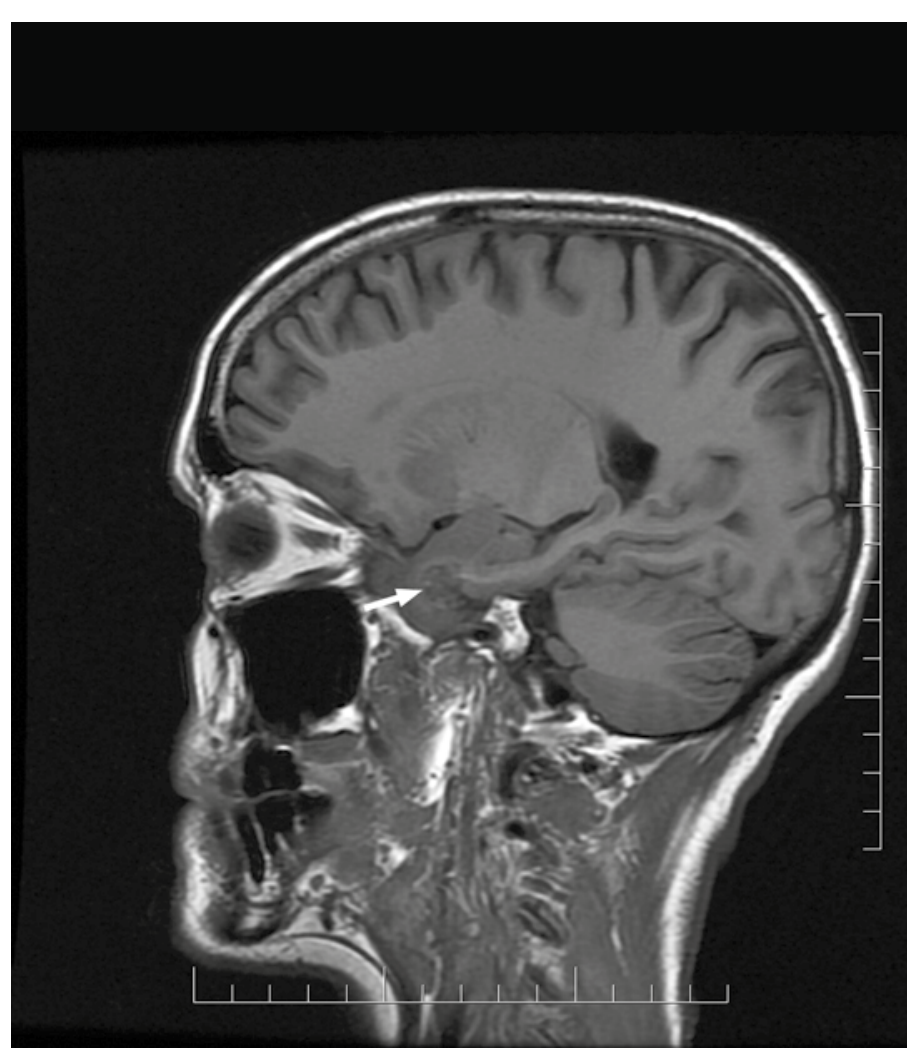

Obr. 4. T2*gre (gradientnísekvence) podstatně citlivějšín a susceptibilníartefakty než klasická spinovánebo turbospinová sekvence; susceptibilního efektu se využivá prì detekci drobných dep hemosiderinu po často nepatrných zakrváceních do kavernomů - tato sekvence má největšípotenciál odhalit prípadnédalši ijen tečkovité léze (kavernomy bývajíve značném procentu vicečetné); lézejev této sekvenci téměr v celém rozsahu asignální, je nápadnější a zdá se objemnější

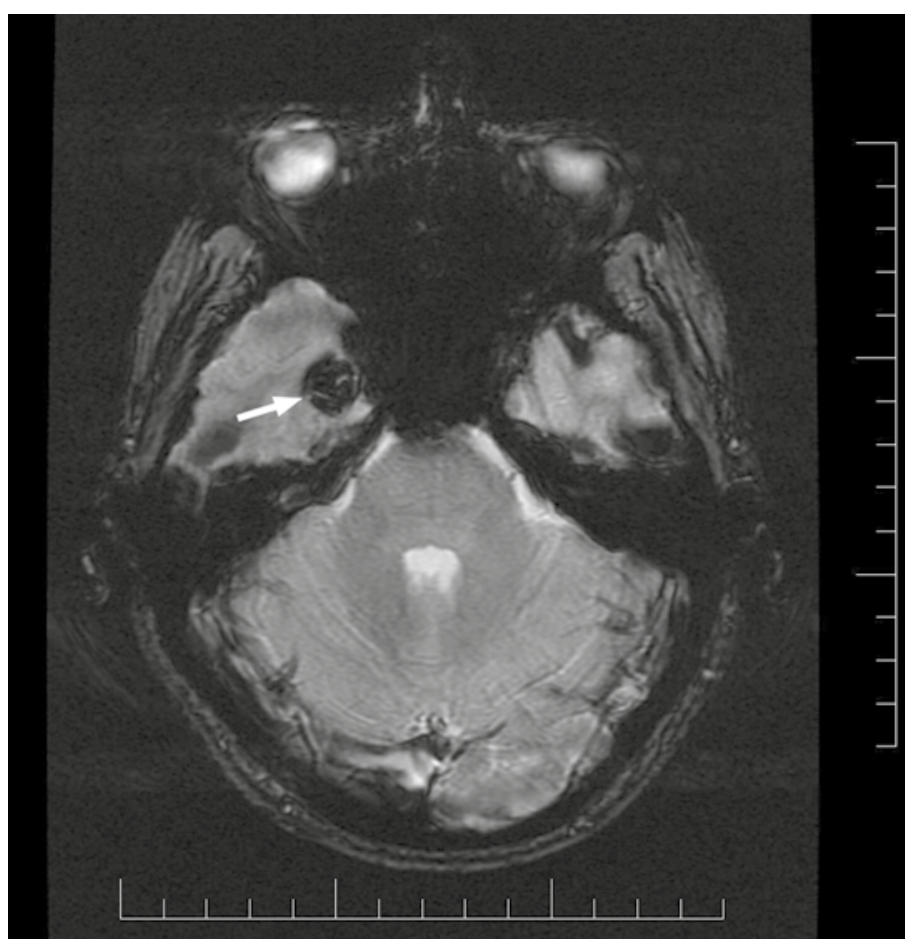

